\title{
School Based Intervention sebagai Upaya Perbaikan Konsumsi Buah dan Sayur Siswa Sekolah Dasar
}

\section{School Based Intervention as a Strategy to Improve Fruit and Vegetable Consumption of Elementary School Students}

\author{
Damelya Patricksia Dampang*, Lilik Kustiyah, Cecilia Meti Dwiriani \\ Departemen Gizi Masyarakat, Fakultas Ekologi Manusia, Institut Pertanian Bogor \\ (*patricksiadampang@gmail.com)
}

\begin{abstract}
ABSTRAK
Anak usia sekolah rentan mengalami masalah gizi salah satunya dikarenakan faktor lingkungan, terutama lingkungan fisik yang menyediakan makanan secara luas, terjangkau dan densitas energi lebih tinggi serta kurangnya konsumsi buah dan sayur. Upaya yang dilakukan untuk meningkatkan kebiasaaan makan buah dan sayur pada anak sekolah adalah adanya school based intervention. Penelitian bertujuan menganalisis pengaruh program school based intervention terhadap peningkatan konsumsi buah dan sayur siswa sekolah dasar. Penelitian berlangsung dari Februari sampai Mei 2017 di Nganjuk, Jawa Timur. Penelitian ini menggunakan desain eksperimental dengan pre-post intervention dengan jumlah subjek yakni 50 siswa (10-13 tahun) yang diberikan tiga jenis intervensi, yaitu school gardening, cooking class, dan pemberian buah dan sayur dalam bentuk olahan disekolah. Hasil penelitian menunjukkan bahwa dengan adanya ketiga intervensi tersebut dapat meningkatkan konsumsi buah dan sayur siswa yakni $130 \mathrm{~g} / \mathrm{hr}$ dan $100 \mathrm{~g} / \mathrm{hr}$ dan ketersediaan buah dan sayur di rumah meningkat yakni 81 g/minggu dan $182 \mathrm{~g} /$ minggu. Hasil recall SQ-FFQ 2x24 jam menunjukkan rata-rata konsumsi padat energi berkurang dari $1420 \mathrm{kkal}$ menjadi $1241 \mathrm{kkal}$. Berdasarkan hasil tersebut maka school based intervention dapat dijadikan sebagai salah satu strategi untuk meningkatkan konsumsi buah dan sayur serta ketersediaan buah dan sayur di rumah.
\end{abstract}

Kata kunci : Konsumsi buah dan sayur, school based intervention, siswa sekolah dasar

ABSTRACT

School age children are susceptible to experiencing nutritional problems, one of which is due to environmental factors, especially the physical environment which provides broad, affordable food, higher energy density and lack of consumption of fruits and vegetables. The efforts to improve the habit of eating fruits and vegetables in school children is the existence of school based intervention. This study aim to analyze the effect of school based intervention program to increase of fruit and vegetable consumption of elementary school students. The study took place from February to May 2017 in Nganjuk, East Java. This study used experimental design with pre-post intervention with the number of subjects is 50 students (10-13 years) given three types of interventions is school gardening, cooking class, and giving of fruit and vegetables in school. The results showed that the presence of these three interventions can increased fruit consumption $130 \mathrm{~g} /$ day and vegetable $100 \mathrm{~g} /$ day and the availability of fruit and vegetables at home increased $81 \mathrm{~g} /$ week and $182 \mathrm{~g} /$ week. The results from recall SQ-FFQ $2 \times 24$ hours showed the average consumption of energy density decreased from $1420 \mathrm{kcal}$ to $1241 \mathrm{kcal}$. Based on these results, school based intervention can be used as a strategy to increase fruit and vegetable consumption and availability fruit and vegetable at home

Keywords : Fruit and vegetable consumption, school based intervention, elementary school students 


\section{PENDAHULUAN}

Buah dan sayur memiliki banyak manfaat bagi kesehatan karena kaya akan serat dan mikronutrien (vitamin, mineral, dan beragam fitokimia terutama antioksidan) yang bermanfaat bagi kesehatan. ${ }^{1}$ Setiap tahun 2,7 juta jiwa dapat diselamatkan dengan konsumsi berbagai jenis buah dan sayuran yang cukup. ${ }^{2}$ Meningkatkan konsumsi buah dan sayur sampai 600 gram per hari dapat mengurangi beban penyakit diseluruh dunia sebesar $1,8 \%$, penyakit jantung $31 \%$, stroke $19 \%$, kanker esofagus $20 \%$, dan kanker paru-paru $12 \%{ }^{3}$

Riset Kesehatan Dasar (Riskesdas) tahun 2007 menunjukkan bahwa proporsi penduduk Indonesia umur 10 tahun ke atas kurang konsumsi buah dan sayur masih tinggi sebesar 93,6\%, tidak berbeda jauh dari tahun 2013 sebesar 93,5\%. ${ }^{4}$ Hasil survei Studi Diet Total (SDT) oleh Balitbangkes tahun 2014 menunjukkan bahwa anak usia 5-12 tahun hanya mengonsumsi 33,9 gram sayuran per orang per hari sedangkan konsumsi buah paling banyak adalah buah pisang 10,1 gram per orang per hari. ${ }^{5}$ Rerata konsumsi buah di Jawa Timur sebesar 27,5 g/kap/hari dan konsumsi sayur adalah 53,8 $\mathrm{g} / \mathrm{kap} / \mathrm{hari}$ dibandingkan rerata konsumsi buah dan sayur nasional yaitu 33,5 g/ kap/hari dan 57,1 g/kap/hari. ${ }^{4}$ Konsumsi buah dan sayur merupakan bagian dari sepuluh pesan gizi utama dalam Pedoman Gizi Seimbang (PGS), yaitu banyak makan sayuran dan cukup buah-buahan dengan rekomendasi PGS untuk anak usia 10-12 tahun sebesar 3 porsi/hari untuk sayur dan 4 porsi/ hari untuk buah. ${ }^{5}$

Kampanye buah dan sayur telah banyak dilakukan negara-negara di dunia salah satunya di Amerika dengan program school based intervention sebagai strategi yang menjanjikan untuk meningkatkan kebiasaan makan pada anak. ${ }^{6}$ School gardening yang dilakukan pada anak sekolah dasar merupakan komponen yang penting sebagai pendidikan gizi untuk meningkatkan pengetahuan dan perubahan perilaku konsumsi buah dan sayur pada anak. ${ }^{7}$ Pengalaman berkebun di sekolah pada siswa dapat meningkatkan konsumsi sayur termasuk pengenalan, kesukaan dan kesediaan untuk mencoba berbagai sayuran. ${ }^{8}$ School gardening dan cooking program yang dilakukan pada siswa sekolah dasar kelas 3, 4 dan 5 yang $50 \%$ dari siswa tersebut mengalami obesitas menunjukkan bahwa program ini mendorong anak untuk memilih dan mengonsumsi lebih banyak buah dan sayur. ${ }^{9}$

Pemanfaatan kebun sekolah di Indonesia banyak digunakan sebagai pembelajaran biologi siswa. ${ }^{10}$ Adapun yang melihat school gardening sebagai upaya untuk memperkenalkan budidaya sayuran pada anak-anak sekolah, ${ }^{11}$ tetapi belum ada yang melihat school based intervention sebagai potensi dalam meningkatkan pengetahuan, sikap dan praktik konsumsi buah dan sayur pada anak sekolah dasar.

Pertanian di lingkungan sekolah secara langsung maupun tidak langsung dapat memberikan sosialisasi kepada banyak pihak untuk memahami pertanian, mengelola sumber daya lahan yang terbatas dan secara umum mengembangkan budidaya sayuran. Adanya produksi yang berkesinambungan sangat dibutuhkan dalam upaya menunjukkan pola tanam yang berkeseinambungan agar memberikan hasil setiap saat. Dengan begitu pemenuhan akan konsumsi buah dan sayur anak dapat dipenuhi serta di lain pihak akan memberdayakan keluarga dan masyarakat dalam mengembangkan usaha tani keluarga melalui pengembangan pasar. ${ }^{12}$ School based intervention diharapkan mampu berperan dalam memberikan terobosan untuk membantu menjawab permasalahan gizi anak sekolah terutama membantu anak untuk lebih sering mengonsumsi buah dan sayuran yang ditanam melalui pengalaman berkebun dan masak bersama sehingga dapat meningkatkan konsumsi buah dan sayur pada anak usia sekolah dasar. Penelitian bertujuan menganalisis pengaruh school based intervention untuk meningkatkan konsumsi buah dan sayur pada siswa Sekolah Dasar (SD).

\section{BAHAN DAN METODE}

Penelitian ini menggunakan desain eksperimental dengan metode pre-post intervention yaitu desain penelitian yang tidak melakukan pengacakan pada responden secara individu tanpa menggunakan kelompok kontrol. ${ }^{13}$ Penelitian dilaksanakan di Sekolah Dasar Plus An-Nahdlah Gondang, Kabupaten Nganjuk, Jawa Timur yang berlangsung 4 bulan sejak Februari sampai Mei 2017. Populasi penelitian adalah seluruh siswa SD Plus An-Nahdlah Gondang Kabupaten Nganjuk dan subjek dalam penelitian ini adalah siswa kelas 
4 dan 5 dengan jumlah subjek 50 siswa. Pemilihan sekolah dilakukan secara purposive berdasarkan kriteria ketersediaan lahan, kesediaan sekolah sebagai tempat penelitian dan belum pernah mendapatkan intervensi serupa dan kriteria subjek dalam penelitian ini yakni siswa pada tingkat kelas 4 dan $5 \mathrm{SD}$, dalam keadaan sehat dan bersedia mengikuti penelitian hingga selesai dan telah menandatangani informed consent. Penelitian ini telah mendapatkan Persetujuan Etik dari Komite Etik Penelitian Kesehatan Fakultas Kedokteran Universitas Indonesia No.85/UN2.F2/ETIK/2017.

Terdapat 3 jenis intervensi dalam penelitian ini. Tahapan intervensi berupa school gardening pada bulan 1 dilakukan satu kali setiap minggu selama 60 menit, bulan ke 2 adalah cooking class dilakukan satu kali seminggu 60 menit, dan bulan ke 3 dan 4 merupakan periode praktik konsumsi buah dan sayur yang disediakan oleh peneliti yang dilakukan dua kali dalam seminggu selama 30 menit. Ukuran kebun yang digunakan adalah $7 \mathrm{~m} \times 7 \mathrm{~m}$ yang dibagi menjadi delapan sub-lahan berukuran $50 \mathrm{~cm}$ dengan jarak tanaman 1 ke tanaman lainnya $37,5 \mathrm{~cm}$. Jenis sayur-sayuran yang dipilih adalah sawi hijau, pakchoy, tomat, selada, terong hijau, terong ungu dan kangkung. Cooking class merupakan praktik memasak sayuran yang diakhiri dengan makan bersama sayur hasil memasak. Menu yang dipilih secara berurut yaitu capcay dan buah belimbing yang disediakan dalam bentuk buah potong pada minggu pertama, cah kangkung dan sop buah pada minggu ke dua, sop sayur dan buah salak pada minggu ketiga, kerupuk pecel dan buah pepaya potong pada minggu keempat. Kegiatan ini melibatkan subjek mulai dari persiapan sampai penyajian buah dan sayur. Pemberian buah dan sayur diberikan $2 \mathrm{kali} /$ minggu pada waktu jam istirahat yaitu pukul 09.00. Subjek diberikan leaflet tentang buah dan sayur yang berisi informasi berupa jenis-jenis buah dan sayur, kandungan gizi dan serat serta manfaatnya bagi kesehatan.

Data karakteristik siswa, pengetahuan, sikap, preferensi dan kebiasaan makan buah dan sayur dikumpulkan dengan kuesioner yang pengisiannya dipandu oleh peneliti. Berat badan diukur dengan timbangan digital dan tinggi badan diukur dengan microtoice. Ketersediaan buah dan sayur di rumah subjek diukur dengan menggunakan kuesioner selama 7 hari terakhir. Pemberian kue- sioner kepada ibu/wali yang bertanggungjawab dalam penyediaan makanan melalui siswa untuk diisi di rumah dan dikembalikan melalui siswa, tetapi terlebih dahulu subjek diberikan contoh cara mengisi kuesioner agar dapat membantu ibu/wali dalam mengisi kuesioner ketersediaan buah dan sayur di rumah. Data yang diperoleh kemudian dicatat/entry ke komputer dengan menggunakan Microsoft excel 2016 dan analisis statistik dilakukan dengan menggunakan SPSS 16.0 for Windows. Analisis secara deskriptif meliputi frekuensi, ratarata, standar deviasi, median, minimum dan maksimum. Analisis bivariat digunakan untuk mengetahui hubungan antara variabel independen dan dependen menggunakan paired sample T-Test. Penyajian data dalam penelitian ini menggunakan tabel distribusi dan analisis bivariat.

\section{HASIL}

Penilaian status gizi subjek mengacu pada standar WHO dengan menggunakan ukuran $z$-score Indeks Massa Tubuh menurut umur (IMT/U). Hasil menunjukkan bahwa terjadi perbaikan gizi pada saat pengukuran setelah intervensi yaitu subjek dengan status gizi kurang menjadi tidak ada sedangkan proporsi subjek pada status gizi kurus, gemuk dan obesitas menurun, serta subjek dengan status gizi normal meningkat.

Tabel 1 menunjukkan bahwa sebanyak 60\% responden berjenis kelamin perempuan dan rata rata umur responden 11.56 tahun dan rata - rata uang saku responden sebesar Rp. 3.660,-. Tabel 2 menunjukkan bahwa pada masing - masing kelompok paling banyak responden dengan status gizi normal (52\% pada perlakuan I) dan $(68 \%$

\section{Tabel 1. Karakteristik Responden}

\begin{tabular}{ccc}
\hline Karakteristik & $\mathbf{n}$ & $\mathbf{\%}$ \\
\hline Jenis Kelamin & & \\
Laki-laki & 20 & 40 \\
Perempuan & 30 & 60 \\
Umur & & \\
10-11 tahun & 21 & 42 \\
12-13 tahun & 29 & 58 \\
Mean \pm SD & $11.56 \pm 0.675$ & \\
Uang saku & & \\
< Rp. 3000 & 23 & 46 \\
> Rp. 3000 & 27 & 54 \\
Mean \pm SD & $3660 \pm 745.326$ & \\
\hline
\end{tabular}


Tabel 2. Karakteristik Status Gizi Responden

\begin{tabular}{lcccc}
\hline \multirow{2}{*}{ Status Gizi } & \multicolumn{2}{c}{ Pengukuran I } & \multicolumn{2}{c}{ Pengukuran II } \\
\cline { 2 - 5 } & $\mathbf{n}$ & $\mathbf{\%}$ & $\mathbf{n}$ & $\mathbf{\%}$ \\
\hline Sangat kurus & 2 & 4 & - & - \\
Kurus & 5 & 10 & 4 & 8 \\
Normal & 26 & 52 & 34 & 68 \\
Gemuk & 8 & 16 & 5 & 10 \\
Obesitas & 9 & 18 & 7 & 14 \\
\hline Mean \pm SD & \multicolumn{2}{c}{$0.36 \pm 2.21$} & \multicolumn{2}{c}{$0.51 \pm 1.74$} \\
\hline
\end{tabular}

Tabel 3. Sebaran Subjek Berdasarkan Kategori Pengetahuan dan Sikap tentang Buah dan Sayur

\begin{tabular}{|c|c|c|c|c|c|c|}
\hline \multirow{3}{*}{ Variabel } & \multicolumn{6}{|c|}{ Perlakuan ke- } \\
\hline & & $\begin{array}{c}I \\
\mathbf{n}(\%)\end{array}$ & & & $\begin{array}{c}\text { II } \\
\text { n(\%) }\end{array}$ & \\
\hline & Kurang & Cukup & Baik & Kurang & Cukup & Baik \\
\hline Pengetahuan & $14(28)$ & $26(52)$ & $10(20)$ & $9(18)$ & $26(52)$ & $15(30)$ \\
\hline Sikap & $8(16)$ & $37(74)$ & $5(10)$ & $4(8)$ & $39(78)$ & $7(14)$ \\
\hline
\end{tabular}

Tabel 4. Perubahan Nilai Pengetahuan dan Sikap tentang Buah dan Sayur Subjek

\begin{tabular}{lcc}
\hline & Pengetahuan tentang Buah dan Sayur & Sikap tentang Buah dan Sayur \\
\cline { 2 - 3 } & Mean \pm SD & Mean \pm SD \\
\hline Sebelum & $6.66 \pm 2.07$ & $7.02 \pm 1.31$ \\
Sesudah & $7.44 \pm 1.72$ & $7.26 \pm 1.20$ \\
$\Delta$ & $0.80 \pm 1.92$ & $0.22 \pm 1.41$ \\
$\mathrm{p}$ & 0.007 & 0.234 \\
\hline
\end{tabular}

*Berhubungan signifikan pada $\mathrm{p}<0.05$ dengan uji beda paired sample $t$-test

pada perlakuan II).

Pengetahuan dan sikap subjek dinilai dari 10 pertanyaan yang diberikan. Pertanyaan terdiri dari jenis buah dan sayur, kandungan gizi, serat dan manfaatnya serta porsi buah dan sayur. Khomsan et al., tahun 2000 mengkategorikan pengetahuan dan sikap menjadi 3 kategori yaitu baik $(>80 \%)$, sedang (60-80\%), dan kurang $(<60 \%)$ (Tabel 3$)$. Hasil menunjukkan bahwa dengan adanya intervensi school based intervention dapat menurunkan proporsi kategori subjek pengetahuan dan sikap kurang terkait buah dan sayur, meningkatkan pengetahuan dan sikap subjek pada kategori baik, sedangkan pada kategori normal untuk pengetahuan tidak berubah. Hasil uji beda paired sample t-test menunjukkan bahwa pengetahuan dan sikap subjek tentang buah dan sayur tidak menunjukkan perubahan yang signifikan $(p<0,05)$ tetapi cenderung meningkat (Tabel 4).

Data preferensi buah dan sayur diperoleh dengan menjawab pertanyaan terbuka menge- nai buah dan sayur yang paling disukai dan tidak disukai beserta alasannya. Terdapat 3 jenis buah yang paling disukai subjek secara berurut adalah jeruk (50\%), rambutan (44\%) dan semangka $(40 \%)$. Alasan subjek menyukai buah-buah tersebut karena rasanya manis (27\%), enak (24\%), dan menyegarkan (11\%). 5 jenis sayur yang paling disukai subjek secara berurut yaitu jamur (58\%), bayam (56\%) dan wortel (50\%). Alasan subjek menyukai sayur-sayur tersebut karena rasanya enak (31\%), menyehatkan (11\%) dan mengandung banyak vitamin (10\%).

Buah yang paling tidak disukai subjek secara berurut adalah durian (54\%), nanas (40\%) dan sawo (32\%). Alasan subjek tidak menyukai buah-buah tersebut karena rasanya tidak enak $(30 \%)$, pahit (20\%), dan asam (11\%). Sayur yang paling tidak disukai subjek secara berurut yaitu melinjo (54\%), terong (36\%) dan tauge (34\%). Alasan siswa tidak menyukai sayur-sayur tersebut karena rasanya tidak enak (60\%), pahit (40\%) dan 
Tabel 5. Jumlah dan Porsi Konsumsi Buah dan Sayur Subjek

\begin{tabular}{lcccc}
\hline & \multicolumn{2}{c}{ Konsumsi Buah } & \multicolumn{2}{c}{ Konsumsi Sayur } \\
\cline { 2 - 5 } & g/hr & porsi/hr & g/hr & porsi/hr \\
\hline Sebelum & $140 \pm 1.07$ & $2.80 \pm 2.15$ & $46.73 \pm 3.91$ & $0.93 \pm 0.79$ \\
Sesudah g/hr & $270 \pm 8.25$ & $5.41 \pm 1.65$ & $100 \pm 6.13$ & $2.01 \pm 1.22$ \\
$\Delta$ & $130 \pm 99.04$ & $2.61 \pm 1.98$ & $53.9 \pm 69.50$ & $1.08 \pm 1.40$ \\
p & $0,000^{* *}$ & $0.000^{* *}$ & $0,000^{* *}$ & $0.000^{* *}$ \\
\hline
\end{tabular}

*Berhubungan signifikan pada $\mathrm{p}<0.05$ dengan uji beda paired sample t-test

Tabel 6. Jumlah dan Frekuensi Ketersediaan Buah dan Sayur di Rumah

\begin{tabular}{cccc}
\hline \multicolumn{5}{c}{ Pengukuran ke-I } & Pengukuran ke-II & p \\
\hline \multicolumn{5}{c}{ Mrekuensi ketersediaan buah dan sayur } & & \\
\hline \multicolumn{5}{c}{ Median (Min, Maks) } \\
\hline Buah (hari/minggu) & $5(0,7)$ & $6(0,7)$ & 0.073 \\
Sayur (hari/minggu) & $6(1,7)$ & $7(4,7)$ & $0.013^{*}$ \\
\hline Jumlah ketersediaan buah dan sayur di rumah & \\
\hline \multicolumn{5}{c}{ Rata-Rata \pm SD } \\
\hline Buah (g/minggu) & $340 \pm 2199.49$ & $421 \pm 2441.28$ & 0.561 \\
Sayur (g/minggu) & $234 \pm 1270.11$ & $416 \pm 6130.18$ & $0.038^{*}$ \\
\hline
\end{tabular}

${ }^{*}$ Berhubungan signifikan pada $\mathrm{p}<0.05$ dengan uji beda paired sample t-test

asam (11\%).

Konsumsi buah dan sayur meningkat sangat signifikan $(\mathrm{p}<0,05)$ setelah dilakukan intervensi (Tabel 5), yakni masing-masing meningkat sebesar $130 \mathrm{~g} /$ hari (93\%) dan 53,27 g/hari (114\%). Demikian pula porsi buah dan sayur yang dikonsumsi juga meningkat signifikan, yakni masing-masing sebesar 2,61 porsi/hari (93\%) dan 1,08 porsi/hari $(115 \%)$. Ketersediaan buah tidak menunjukkan perubahan yang signifikan jika dilihat dari nilai $\mathrm{p}>0,05$, tetapi cenderung meningkat pada pengukuran II (Tabel 6). Hasil menunjukkan bahwa frekuensi ketersediaan buah meningkat dari pengukuran I yang disediakan 5 hari/minggu menjadi 6 hari/minggu dan jumlah ketersediaan buah meningkat $24 \%$ ( $81 \mathrm{~g} / \mathrm{minggu})$. Peningkatan yang signifikan $(\mathrm{p}<0,05)$ terjadi pada frekuensi dan jumlah ketersediaan sayur di rumah. Frekuensi ketersediaan sayur meningkat dari 6 hari/minggu menjadi 7 hari/minggu dengan rata-rata ketersediaan sayur naik sebesar 78\% (182 g/minggu).

\section{PEMBAHASAN}

Perbaikan status gizi subjek diduga berkaitan dengan perbaikan konsumsi pangan dan aktivitas fisik. Perbaikan konsumsi pangan dalam penelitian ini ditunjukkan oleh berkurangnya kon- sumsi makanan dengan energi tinggi dan meningkatnya secara signifikan konsumsi buah dan sayur. Hasil recall SQ-FFQ 2x24 jam menunjukkan ratarata konsumsi makanan padat energi berkurang dari 1420 kkal menjadi 1241 kkal dalam 2 hari. Berbagai penelitian juga mengindikasikan bahwa berkurangnya prevalensi subjek yang gemuk dan obesitas berkaitan dengan meningkatnya aktivitas fisik dan dalam penelitian ini yang meningkat adalah aktivitas berkebun dan kegiatan masak bersama yang sebelum intervensi aktivitas tersebut tidak ada. Hal ini sejalan dengan penelitian Hermann et al. yang menunjukkan bahwa program berkebun di sekolah dapat meningkatkan $44 \%$ konsumsi buah dan sayur setiap hari dan 79\% meningkatkan aktivitas fisik. ${ }^{14}$ Wells et al. juga menunjukkan bahwa siswa yang mendapatkan intervensi berkebun di sekolah lebih baik dalam mengurangi kebiasaan aktivitas sedentary dibanding kelompok yang tidak mendapatkan intervensi berkebun di sekolah. Aktivitas yang paling banyak dilakukan adalah berdiri (17.51\%) dan berjalan $(9.11 \%) .{ }^{15}$

Pertanyaan tentang pengetahuan buah dan sayur terdiri dari 10 pertanyaan pilihan ganda. Subjek yang menjawab benar paling banyak tentang jenis buah dan jenis sayur, kandungan buah dan sayur serta manfaat vitamin $\mathrm{C}$ dan vitamin 
A. Sikap tentang buah dan sayur terdiri dari 10 pernyataan, subjek yang merespon dengan positif (setuju) terdapat pada konsumsi buah dan sayur beraneka ragam tiap hari, manfaat buah dan sayur untuk daya tahan tubuh, buah dan sayur bergizi tidak harus mahal dan jenis sayur yang memiliki kandungan vitamin dan mineral. Pengetahuan dan sikap subjek cenderung meningkat, tetapi tidak berubah signifikan. Hal ini tidak sejalan dengan beberapa penelitian yang mengungkapkan bahwa program berkebun di sekolah dapat membantu anak memilih makanan sehat. ${ }^{16}$ Pengetahuan yang baik tidak selalu didukung oleh sikap yang positif. Pola asuh orang tua terhadap perilaku anak juga mampu memberikan pengaruh terhadap konsumsi buah dan sayur. Kebiasaan orang tua untuk mengonsumsi buah dan sayur memiliki hubungan yang bermakna dengan konsumsi buah dan sayur pada anak. Anak akan mengonsumsi buah dan sayur dengan mengamati contoh dari orang tua mereka. ${ }^{17}$

Rekomendasi dari Kemenkes tahun 2015 dalam Pedoman Gizi Seimbang (PGS) adalah 4 porsi/hari atau setara dengan $200 \mathrm{~g} /$ hari untuk buah dan 3 porsi/hari atau setara $300 \mathrm{~g} /$ hari untuk sayur. Dengan demikian adanya intervensi school based intervention meningkatkan konsumsi buah dan sayur pada subjek. Konsumsi buah pada subjek sudah sesuai dengan PGS yaitu konsumsi buah 4 porsi per hari atau setara dengan $200 \mathrm{~g}$, sedangkan konsumsi sayur masih lebih rendah daripada anjuran dalam PGS yaitu 3 porsi per hari atau setara dengan $300 \mathrm{~g}$.

Program school based intervention mulai dipandang sebagai strategi yang menjanjikan untuk meningkatkan kesukaan dan asupan dari buah dan sayur. Salah satu cara yang dianjurkan untuk meningkatkan konsumsi buah dan sayur adalah dengan lebih sering menawarkan buah dan sayur di rumah, saat sarapan atau dengan membawa buah sebagai bekal. ${ }^{18}$ Ketersediaan buah dan sayur, kesukaan, pengetahuan orang tua, paparan iklan televisi dan banyaknya jajanan yang tersedia di sekolah merupakan faktor-faktor penentu pemilihan anak dalam konsumsi buah dan sayur. ${ }^{19}$ Dengan peran orang tua dalam menyiapkan buah dan sayur untuk bekal anak dapat mencegah anak jajan sembarangan di sekolah. Konsumsi jajanan di sekolah memberikan kontribusi terhadap asupan energi sebesar $22.9 \%$ dan protein sebesar $15.9 \% .^{20}$ Selain itu, lingkungan sekolah termasuk guru juga berperan dalam pembentukan perilaku anak usia sekolah. Guru merupakan seseorang yang mampu menyampaikan ilmu yang dimiliki dengan baik, menunjukkan sikap positif dan praktik yang baik terutama dalam mengonsumsi makanan yang bergizi dana aman. ${ }^{21}$ Penelitian kualitatif yang dilakukan Power et al., tahun 2008 menunjukkan bahwa salah satu cara berperilaku sehat adalah dengan siswa diperkenalkan pada beberapa makanan sehat seperti buah dan sayur di lingkungan sekolah. ${ }^{22}$ Pemberian kudapan buah dan sayur pada subjek dijam istirahat berpengaruh pada keinginan subjek jajan dikantin. Hal ini dapat dimanfaatkan untuk mengalihkan rasa ingin subjek untuk mengkonsumsi kudapan yang tidak sehat menjadi sehat dan aman.

School gardening yang menyenangkan yang dilakukan pada anak kelas 3 dapat meningkatkan kesukaan dan konsumsi sayuran yang lebih tinggi dibandingkan dengan anak yang tidak memiliki pengalaman berkebun di sekolah. ${ }^{24} \mathrm{Hal}$ ini didukung juga bahwa dampak dari adanya kitchen program pada siswa sekolah dasar mampu meningkatkan kepercayaan diri, membangun kemampuan sosial dan kerjasama dalam sebuah komunitas. ${ }^{25}$ Pengamatan di lapangan menunjukkan bahwa program cooking class yang diakhiri dengan makan bersama dan pemberian buah dan sayur pada subjek dapat mempengaruhi kesukaan buah dan sayur pada subjek, seperti sebagian subjek tidak suka makan buah nenas, tetapi ketika melihat subjek yang lain konsumsi buah nenas maka ada rasa keinginan untuk mengikuti konsumsi buah nenas juga. Sikap positif siswa juga ditunjukkan dengan partisipasi siswa dalam memilih menu kudapan. Kunci agar program kebun sekolah tetap berlanjut adalah dengan adanya kerjasama antara administrator, penanggungjawab/kordinator kebun, guru, dan orang tua/masyarakat. ${ }^{26}$

\section{KESIMPULAN DAN SARAN}

Adanya intervensi school based intervention yang terdiri dari school gardening, cooking class, dan pemberian buah dan sayur cenderung meningkatkan pengetahuan dan sikap terkait buah dan sayur. Peningkatan pengetahuan subjek tentang buah dan sayur sebesar 0.80 dan pada 
sikap subjek terhadap buah dan sayur meningkat 0.22 setelah intervensi. Tiga jenis intervensi yang diberikan dapat meningkatkan konsumsi buah sebesar 93\% (130 g/hari) dan sayur sebesar 114\% $(53.27 \mathrm{~g} /$ hari). Selain itu, dengan adanya intervensi school based intervention dapat meningkatkan ketersediaan buah $24 \%$ ( $81 \mathrm{~g} /$ minggu) dan sayur $78 \%$ (182 g/minggu) di rumah. Dengan demikian, adanya intervensi school based intervention dapat mencukupi kebutuhan konsumsi buah pada subjek sudah sesuai dengan PGS, sedangkan konsumsi sayur masih lebih rendah daripada anjuran dalam PGS dan meningkatkan ketersediaan buah dan sayur di rumah.

Adapun saran dari penelitian ini adalah 1) siswa lebih sering diperkenalkan tentang buah dan sayur termasuk jenis buah dan sayur, kandungan gizi dan serat, manfaat untuk kesehatan serta porsi buah dan sayur yang perlu dikonsumsi setiap hari; 2) Mempertahankan peningkatan ketersediaan buah dan sayur di rumah dengan menyediakan setiap hari di rumah agar dapat dikonsumsi oleh seluruh keluarga; 3) Pihak sekolah agar dapat melanjutkan program school based intervention sehingga dapat meningkatkan pengetahuan, sikap, konsumsi buah dan sayur serta ketersediaan buah dan sayur di sekolah dan dapat menambahkan materi tentang kesehatan seperti konsumsi buah dan sayur dan manfaatnya ke dalam mata pelajaran PAI (Pendidikan Agama Islam) tentang makanan halal; 4) Dinas kesehatan melakukan penyuluhan atau memberikan edukasi pendidikan gizi terhadap guru, orang tua dan masyarakat dengan melibatkan dinas pertanian, perusahaan ataupun LSM terkait yang dapat membantu penyediaan sarana dan prasarana program school based intervention; 6) Konsep school based intervention dapat diterapkan di skala rumah tangga, sekolah dan masyarakat dengan tetap mempertimbangkan tersedianya lahan, fasilitas air dan jenis buah dan sayuran dengan umur panen yang relatif pendek di lokasi program yang akan diadakan sehingga dapat membantu memenuhi kebutuhan buah dan sayur harian.

\section{DAFTAR PUSTAKA}

1. Slavin J \& Lloyd B. Health Benefits of Fruits and Vegetables. American Society for Nutrition. 2012;3(3):506-16.
2. WHO/FAO. Report of a joint WHO/FAO Expert Consultastion: Diet, Nutrition, and the Prevention of Chronic Disease. Geneva: WHO; 2003.

3. Lock K, Pomerleau J, Causer L, et al. The Global of Disease Attributable to Low Consumption of Fruit and Vegetables: Implications for the Global Strategy on diet. Bulletin of the World Health Organization. 2005;83(2).

4. Kemenkes RI. Riset Kesehatan Dasar 2013. Jakarta: Kementerian Kesehatan RI; 2013.

5. Kemenkes RI. Konsumsi Makanan Individu. Jakarta: Kementerian Kesehatan RI; 2014.

6. National Gardening Association. 2014. [Diakses pada tanggal 20 Januari 2017]. Available at: http://garden.org.

7. Parmer MS, Glennon SJ, Shannon D, et al. School Gardens: An Experential Learning Approach for a Nutrition Education program to increase Fruit and Vegetable Knowledge, Preference, and Consumption Among Second-grade Students. Journal of Nutrition Education and Behavior. 2009;41(3):212-17.

8. Ratcliffe MM, Kathleen MA, Batrice RL, et al. The Effects of School Gardem Experiences on Middle School-Aged Students' Knowledge, Attitudes, and Behaviors Associated with Vegetable Consumption. Health Promotion Practice. 2011;12(1):36-43.

9. Bergman D \& Barry C. "This is Way than Cheetos!": Changing Children's Eating Behavior Through Garden and Kitchen-Based Nutrition Education. Journal of Nutrition Education and Behavior. 2016;48(7):9-14.

10. Nyaraswati, R. Pemanfaatan Kebun Sekolah dalam Pembelajaran Biologi terhadap Hasil Belajar Siswa Kelas VII Semester I SMP N 1 Tunjungan Kabupaten Blora [Skripsi]. Surakarta: Universitas Muhammadiyah Surakarta; 2010.

11. Kariada KI. Desain dan Pengenalan Kebun Sekolah pada Siswa Sebagai Sumber Pangan. Bali: Badan Penelitian dan Pengembangan Pertanian; 2011.

12. Badan Penelitian dan Pengembangan Pertanian, Kementerian Pertanian. "School Garden" Ajarkan Anak Cinta Makan Sayur. Agroinovasi. 2013; Edisi 17-23 April : 3503.

13. Ar D, Jacobs LC, Sorensen C, et al. Intro- 
duction to Research in Education 8th edition. USA (US): Wadsworth Cengage Learning; 2009.

14. Hermann JR, Parker SP, Brown BJ, et al. After School Gardening Improves Children's Reportes Vegetable Intake and Physical Activity. Journal Nutrition Education Behavior. 2006; 412(38):201-204.

15. Wells MN, Myers MB, Henderson RC. School Gardens and Physical Activity: A Randomized Controlled Trial of Low Income Elementary Schools. Preventive Medicine. 2014; 69(5):27-33.

16. Brown J, Colson G, Serre BC, et al. Summer Garden Programs Improve Children's Food Knowledge and Preferences: Evidence Using Stated and Revealed Preference Measures. Hort Technology. 2016;26(2):133-140.

17. Bourdeaudhuij D, Velde S, Brug J, et al. Personal, social and environmental predictors of daily fruit and vegetable intake in 11-year-old children in nine European countries. European Journal Clinical Nutrition. 2008;62:834841.

18. Mittmann S, Austel A, Ellrot T. Determinants of fruit and vegetable consumption in primary school children. Ernahrungs Umschau. 2014; 61(8):124-129.

19. Blanchette L \& Brug J. Determinants of fruit and vegetable consumtion among 6-12 years old children and effective interventions to increase consumption. Journal of Human Nutrition and Dietetics. 2005;18(5):431-443.

20. Rain KD. Determinants of Healthy Eating in
Canada: an Overview and Synthesis. Canadian Public Health Association. 2005;96(3):8-14.

21. Saifah A. Hubungan peran keluarga, guru, teman sebaya dan media massa dengan perilaku gizi anak usia sekolah dasar di wilayah kerja Puskesmas Mabelopura Kota Palu [Tesis]. Depok: Universitas Indonesia; 2011.

22. Power TG, Binder RC, Goetz S, et al. Obesity Prevention in Early Adolescence: Student, Parent and Teacher Views. Journal of School Health. 2008;80(3)13-19.

23. Kemenkes RI. Pedoman Gizi Seimbang: Pedoman Teknis Bagi Petugas Dalam Memberikan Penyuluhan Gizi Seimbang. Jakarta: Kementerian Kesehatan RI; 2015.

24. Evans A, Ranjit N, Fair NC, et al. Previous Gardening Experience and Gardening Enjoyment is Related to Vegetable Preferences and Consumption Among Low-Income Elementary School Children. Journal of Nutrition Education and Behavior. 2016;48(9):618-624.

25. Block K, Gibbs L, Staiger KP, et al Growing Community: The Impact of The Stephanie Alexander Kitchen Garden Program on the Social and Learning Environtment in Primary Schools. Heatlh Education \& Behavior. 2012; 39(4):419-432.

26. Hazzard EL, Moreno E, Beall DL, et al. Best Practices Models for Implementing, Sustaining and Using Instructional School Gardens in California. Journal of Nutrition Education and Behavior. 2011;43(5):409-413. 